\title{
The Crisis in the Foreign Exchange Market
}

\author{
MiCHAEL MELVIN \\ MARK P. TAYLOR \\ CESIFO WORKING PAPER NO. 2707 \\ CATEGORY 7: MONETARY POLICY AND INTERNATIONAL FinanCE \\ JULY 2009
}
An electronic version of the paper may be downloaded
- from the SSRN website: $\quad$ www.SSRN.com
- from the RePEc website: $\quad$ www.RePEc.org
- from the CESifo website: www.CESifo-group.org/wp




\title{
The Crisis in the Foreign Exchange Market
}

\begin{abstract}
The financial crisis of 2007-2008 had major implications for the foreign exchange market. We review events and implications for exchange rates, volatility, returns to currency investing, and transaction costs. This "blow-by-blow" narrative is intended to be a resource for researchers seeking a comprehensive review of the "what, why and when" of the financial crisis in terms of foreign exchange market dynamics. An implementable financial stress index (FSI) is created and then used to illustrate the dramatic nature of the current crisis compared to earlier crises. We also examine how the global FSI might have been used to condition the exposure to the carry trade (long high interest rate currencies, short low interest rate currencies) and we show that such an index has potential value in protecting a portfolio against loss during periods of stress, although this result is subject to the important caveats of controlling for transaction costs and timely recognition of the change in regime.
\end{abstract}

JEL Code: F30, F31.

Keywords: financial crisis, foreign exchange, exchange rates, transaction costs.

\author{
Michael Melvin \\ Barclays Global Investors \\ 400 Howard St \\ USA - San Francisco, CA 94105 \\ michael.melvin@barclaysglobal.com
}

\author{
Mark P. Taylor \\ Barclays Global Investors \\ Murray House \\ UK - Royal Mint Court, London \\ mark.taylor@barclaysglobal.com
}

March 2009 


\section{Introduction}

The global financial crisis of 2007-? is in many respects unparalleled. Compared to the current crisis, recent financial crises such as the 1997 East Asian crisis or the 1998 crisis associated with the collapse of Long Term Capital Management (LTCM) and the Russian bond default had a very much more muted global impact. Of course, these events sent shock waves through global financial markets, but the main damage was fairly contained. It is safe to say that the crisis beginning in 2007 is unlike anything anyone working today has ever lived through before. As a result, it is important to chronicle the major events that have unfolded and their implications.

In this paper, we focus our attention on the foreign exchange (FX) market. Given the relatively low transparency of this market compared to equities and fixed income, it is important to draw on knowledge possessed by market “insiders.” There have been many days of shocking events that have occurred since August 2007 and it is not easy for scholars to appreciate fully the magnitude of the dislocations that have occurred in the FX market. We hope successfully to combine our practitioner insights with the discipline of scholars in order to present a useful analysis of what happened and its importance.

In Section 2 we provide an overview of the important events of the crisis and their implications for exchange rates and market dynamics; the goal is to catalogue all that was truly of major importance in this episode. In Section 3 we construct a quantitative measure of crises that allows for a comparison of the current crisis to earlier events. In addition, we address whether one could have predicted costly events before they happened in a manner that would have allowed market participants to moderate their risk 
exposures and yield better returns from currency speculation. In Section 4 we provides a summary and conclusions.

\section{Crisis Timeline}

The crisis in FX came relatively late. In the early summer of 2007, it was apparent that fixed income markets were under considerable stress. Then, in July 2007 equity markets appeared to experience remarkable volatility. In particular, supposedly market-neutral equity portfolios suffered huge losses and it was common to hear people referring to a “five (or larger) standard deviation event”. FX market participants watched these other markets with growing trepidation, wondering when, if and how the market turbulence would extend to exchange rates. Their fears were met on August 16, 2007: on this date a major unwinding of the carry trade occurred and many currency market investors suffered huge losses. As a result, we date the beginning of the crisis in the FX market as August 2007.

\subsection{August 2007: Contagion from other asset classes and the Carry Trade}

A very popular strategy for currency investors is the so-called "carry trade.” This is a strategy of buying, or taking a long position, in high-interest rate currencies, funded by selling, or taking a short position, in low-interest rate currencies. For instance, in the summer of 2007, many currency investors were short Japanese yen (JPY) and long Australian and New Zealand dollars (AUD and NZD). Interest rate parity (IRP) suggests that the interest differential between two currencies should be offset by a change in the exchange rates. A carry trade investor bets that this exchange rate offset will not occur so 
that the interest differential is earned. So while IRP suggests that, with a low interest rate JPY and a high interest rate NZD, one should observe JPY appreciation relative to the NZD. However, there is a large literature indicating that, in fact, it is often the case that the low interest rate currency actually depreciates rather than appreciates against the high interest rate currency. Such an exchange rate movement results in even larger carry trade profits.

Carry trades tend to unwind during conditions of market stress and relatively modest unwinds have been seen historically once or twice a year on average. Prior to 2007, the most recent major carry trade unwind was in October 1998 following a Russian bond default and the collapse of Long Term Capital Management. ${ }^{1}$ The carry trade unwind occurring on August 16, 2007 was as devastating for many currency managers as was the 1998 episode: the one-day change in the JPY price of the AUD on August 16, 2007 was -7.7 percent, compare to the average daily change in that exchange rate for 2007 prior to August 15 of only 0.7 percent.

Figure 1 displays the returns to the carry trade in 2007 as measured by Deutsche Bank’s Carry Index. Deutsche Bank computes the returns to a portfolio that is long the three highest yielding currencies and short the three lowest yielding currencies across the developed markets. There was a brief period of carry unwind in late-February, earlyMarch associated with an emerging market sell-off that followed a sharp drop in Chinese equity prices. This brief carry unwind was followed by a long run of excellent returns to the carry trade that peaked on July 25. Throughout early August, carry traders experienced a drawdown that culminated in the bloodbath that occurred on August 16. The trough of the return to carry occurred on August 17 and then there was a period of

\footnotetext{
${ }^{1}$ For a description of this episode see Cai, Cheung, Lee, and Melvin (2001).
} 
positive carry-trade performance until November. We therefore identify November as the second stage of the crisis in the FX market.

\section{What caused the carry trade unwind?}

Before discussing November, it is important to ask what triggered the carry unwind in August 2007. The volatility in currency markets followed heightened volatility in other asset classes. Due to losses sustained in fixed income and equity portfolios, it is not surprising that a deleveraging occurred in currency portfolios. Risk appetite fell and investors sought to reduce the size of their exposures to risky trades like the carry trade. This all followed the fallout from the U.S. subprime home loan debacle where the quality of bank loan portfolios became increasingly suspect. Market participants were beginning to discount the degree to which the U.S. subprime problem would become a global issue. Risk concerns drove some investors to reduce their mandates with fund managers who had large subprime exposures. A notable event was the announcement by the hedge fund Sentinel that they were suspending redemptions due to a lack of liquidity. While such announcements were to become fairly commonplace later, August 2007 was still early in the crisis and for a fund manager to inform clients that they could not withdraw their investments sent ripples of fear through the market and reduced risk appetite further.

It is notable, however, that the carry trade unwind of August 2007 was fairly brief as risk came back on later in the month and it appeared that investors viewed the worst as having passed, so that there was the appearance of a move towards more normal market conditions. Beyond the returns to the carry trade depicted in Figure 1, the pattern of turmoil in the FX market is reflected well in the implied volatility from option prices. 
Figure 2 depicts the implied volatility on the AUD-JPY exchange rate for one-month options. This is an interesting exchange rate volatility to study as this is a popular carry trade pair (long AUD, short JPY). Prior to the crisis, if we looked further back in history, we would see a level of volatility of around 8 percent. In August 2007, volatility began to rise and then mid-month the volatility spiked up to 28 percent. As mentioned above, the period of carry unwind and crisis appeared to end quickly so that volatility fell over September and into October. This period of relative calm was about to end in the month of November.

\subsection{November 2007: Credit, Commodities, and Deleveraging}

The second leg of the crisis in currency markets arrived in early November 2007. Figure 1 indicates that the return of the carry trade profitability came to an abrupt halt on November 7. The perception that the world was moving back toward normality had encouraged investors to increase carry trade exposures as the August turmoil faded into the past, but the carry unwind that occurred in November was a stark signal that the crisis was still alive and well. The sell-off of high-yielding currencies was reflected in the AUD-JPY, which moved from a local high of 106.05 on November 7, to 96.17 by November 12, a drop of about 9 percent. Another view is provided in Figure 2, which illustrates how volatility fell following the August crisis period. While volatility remained elevated relative to the pre-crisis period, there had been an uneven pattern of falling volatility on the AUD-JPY until mid-October, when it fell below 14. Volatility then started to rise and jumped dramatically in the second week of November. 


\section{Liquidity and Deleveraging}

What happened to move the crisis into its next stage? Credit concerns seem to be a major part of the story. Firms were finding it difficult to issue asset-backed commercial paper (ABCP) and $\mathrm{ABCP}$ yields were rising dramatically as risk appetite fell and willing lenders were evaporating. There was an obvious flight to quality in that yields on U.S. Treasury bills fell along with the rise in ABCP yields. Bank losses due to securities linked to subprime loans were growing. The CDX and iTRAXX indices indicated that the cost of insuring against default on U.S. and European bonds was growing. Some famous investment managers had suffered serious losses year-to-date and the end result of all this is that a round of pronounced deleveraging was under way. To the extent that investment funds were holding similar positions, when some funds (or even one large fund) sold off its positions, it impacted competitors who suffered losses on their portfolios and led to deleveraging on the part of the competitors as well. There were repeated instances of "forced sales," where losses reached a point such that prime brokers were forcing some funds to liquidate their positions.

The last point is worth further consideration. Hedge funds typically use a prime broker to back their trades so that they stand alongside the creditworthiness of the prime broker in the face of their counterparties. The prime broker banks provide financing to the funds to allow them to obtain the leverage they desire on their investments. The prime brokers impose risk management controls on their clients that can trigger margin calls and/or liquidation of positions. Such controls or triggers could include thresholds for the net asset value of the fund and monthly or quarterly fund returns. If the net asset value or returns fall below the thresholds, this triggers an automatic call from the prime broker to 
either deposit additional cash with the broker or liquidate positions. In a liquidity constrained environment, additional cash is a problem so liquidation occurs. In this manner, a run of bad performance may lead to a cascade of even worse performance as positions are unwound in an illiquid market at the worse possible time. Similarly, if investors choose to redeem their funds they have placed with a fund manager, the manager may be forced to liquidate positions in a very illiquid market and move prices much more than would normally occur. Some funds facing such a situation chose to invoke clauses that blocked the redemptions. The more this occurred, the more risk aversion grew among investors who feared getting stuck in their investments with no liquidity available. All of this contributes to the "flight to quality" away from risky investments and into low-risk investments like Treasury bills and cash.

Beyond the change in risk appetite and associated deleveraging, there was also a fall in commodity prices in November 2007 that reinforced the sell off in so-called commodity currencies like the Australian dollar and Norwegian kroner (NOK). Since these were also high-yielding currencies, this commodity-related selling was just piled on top of the carry unwinding that was ongoing. Whether an investor was long AUD or NOK because of high interest rates or high metals or oil prices, the end result was the same. Their long position suffered a significant loss as these currencies were sold.

\subsection{March 2008: Bear Stearns and Illiquidity}

In early March, rumors of Bear Stearns’ eminent demise began circulating. Despite repeated claims to the contrary by Bear executives, clients feared that the firm would not be able to honor commitments and so began to move their business away from Bear 
Stearns. This included both banks that would provide repo financing as well as prime brokerage clients that feared their cash would be tied up in a bankruptcy. The usual interbank repo sources of short-term funding available to investment banks was evaporating, so the Federal Reserve Bank of New York had to step in and provide a short-term loan to ensure that Bear did not default on any obligations. On March 11, Goldman Sachs allegedly informed hedge fund clients that they would assume no further exposure to Bear Stearns and, by the end of the day, banks were no longer willing to issue credit protection against Bear’s debts. On March 17, JP Morgan Chase offered to buy Bear for $\$ 2$ per share and it was clear that the firm was soon to be taken over. On March 24, the revised offer of \$10 per share was accepted.

The Importance to "too big to fail"

It later would prove to have been an important policy decision for the Federal Reserve to step in and help support the orderly takeover of Bear Stearns and avoid any defaults. In March 2008, one can see in Figures 1-3 that market conditions were deteriorating as fears over the potential failure of a large investment bank and the ripple effects that would have created through the resulting losses imposed on counterparties was being priced into financial markets. Figure 1 indicates that prior to the realization that Bear was cut off from interbank funding, there was a heightened drop in risk appetite and the returns to the carry trade were falling. But once it was clear that Bear was considered "too big to fail" by the Federal Reserve and an orderly takeover by JP Morgan Chase would occur, market fears were calmed and the returns to the carry trade were once more positive into the summer period. Figure 2 illustrates that volatility in the FX market was rising with the 
fear of a potential Bear failure. Volatility spiked to a peak on March 17 and then began to recede following the offer to buy Bear. Volatility continued to fall through late summer. Finally, Figure 3 shows the path of the "TED spread," the difference between the yield on 90 day LIBOR and the yield on 90 day U.S. Treasury bills. Since LIBOR is for unsecured interbank loans while U.S. Treasuries are considered to have no default risk, the TED spread is a measure of credit risk. Figure 3 illustrates that credit risk, as measured by the TED spread, rose rapidly in early March. Once it was clear that Bear would be sold and not go bankrupt, credit risk receded and remained fairly low through the summer.

The second quarter of 2008 was a period when many thought that the world was once again returning to a more normal state for financial markets. For the foreign exchange market, this was a period when risk appetite was increasing and investors were building positions that reflected their view that is was getting safer to speculate in FX. As summer drew to an end, no one expected the storm that was lying just ahead.

\subsection{September 2008: Lehman Brothers and Counterparty Risk}

After relative tranquility through the summer of 2008, the financial crisis soon was to realize its most dramatic episode, the failure of Lehman Brothers. Lehman had huge losses associated with the subprime mortgage business and its stock had fallen dramatically over the year through August. Lehman negotiated with Bank of America and Barclays to try to arrange a sale, but both banks declined to buy the entire company and bankruptcy loomed. The president of the New York Fed called a meeting on Saturday, September 13 to sort out Lehman's future. When negotiations with potential buyers failed to produce a result, there was an exceptional trading session organized on 
Sunday, September 14 to allow firms that were exposed to a Lehman bankruptcy to cover their positions in derivatives contracts. Early the next morning, Lehman's bankruptcy was announced. While Bear Stearns was treated as "too big to fail” by the Federal Reserve and the U.S. Treasury, Lehman Brothers was not so fortunate. This ultimately turned out to be a disastrous decision that imposed losses on other firms across the industry and created turmoil not seen before.

The aftermath of the Lehman failure was startling in its dimensions. Figure 1 shows how the returns to the carry trade had turned down during the summer as the market began to worry about the potential for a disruptive event like the failure of a major bank. The risk aversion and deleveraging that occurred post-Lehman were unlike anything that had been witnessed before. Figure 2 illustrates that volatility was also increasing as the summer came to an end. But following the Lehman debacle, volatility rose to incredible levels that made the earlier peaks in the financial crisis look small in comparison. Finally, Figure 3 gets to the heart of the problem—credit risk. Post-Lehman, there was a dramatic fear across the market as to where losses hid and who might be next to go under. The U.S. government had demonstrated that the market's belief in major institutions being "too big to fail” was misplaced. The failure of Lehman added an entirely new dimension to perceptions of risk.

\section{Counterparty Risk and Liquidity}

In Figure 3, we see how the TED spread rose sharply with the news of the Lehman failure. As mentioned earlier, since LIBOR is a price for unsecured interbank lending, its spread over Treasury bills is a good indicator of the market price of credit risk. Banks were 
hesitant to lend to each other not knowing the details of other balance sheets. Everyone knew that there were many bad assets being carried on bank balance sheets that could ultimately trigger another default. It was in this environment that the Federal Reserve and U.S. Treasury pushed for the TARP (Troubled Assets Relief Program) that was initially stated as a program to remove "troubled assets" from bank balance sheets and reduce the counterparty risk.

As shown in Figure 2, exchange rates experienced unprecedented levels of volatility. In this environment, transaction costs rose dramatically. When market makers provide liquidity to the market, they assume inventory positions in currencies as a result of their trades. They will ultimately seek to cover this inventory risk with offsetting trades. The greater volatility, the greater risk they face from holding positions. As a result, the bid-ask spread rises to compensate them for this risk. In the fall of 2008, FX spreads widened dramatically.

Table 1 provides some indicative data on how spreads changed from pre-crisis normal times to the 2008 post-Lehman crisis. These are indicative of spreads that might be quoted on a bilateral trade between two counterparties. A hedge fund might call a bank marketmaker and request a two-way quote on USDCHF, for instance. In the pre-crisis period, the quoted spot spread might be in the range of 4 "pips." For instance, a spot trade could be quoted at 1.1525-1.1529. During the post-Lehman crisis period, the spread widened to 16 pips. In the worst of times, spreads on particular currencies were even wider than those suggested by Table 1 . Generally spreads were at least 400 percent wider than what used to be considered normal. In addition, there were times in the fall of 2008, 
when it was difficult to trade in normal sizes due to the extreme risk aversion of market makers.

Even more dramatic than the spot spreads was the widening that occurred in spreads for forward delivery. Table 1 also contains data on indicative spreads for 3-month swap quotations. In the pre-crisis normal time, swap spreads on the USDCHF would be around 0.4 pips. In the aftermath of the Lehman Brothers failure, this spread would be about 15 pips. The cost of trading for forward delivery widened by much more than the spot spreads. If one wanted to trade a currency forward, you had to pay a substantial premium compared to the pre-crisis period.

Table 2 contains a table constructed by RBS, that also appeared in an article in the Financial Times, documenting how trading changed on the electronic broker platforms EBS and Reuters. Comparing the pre-crisis period to the crisis period, one can see that there was more trading as the total number of transactions increased from 36 percent for the Mexican peso to 92 percent for the EURUSD. This might suggest that there was more liquidity, but there was actually less dollar value being traded in the crisis period than in the earlier period. The active trading during September-October 2008 may be thought of using the hot-potato analogy, where risk is the hot-potato that is passed from institution to institution until it finds a willing home. The hot potato was being passed faster than ever as no bank wanted to warehouse the intradaily risk as they normally would. The middle column of Table 2 shows that average spreads increased from 60 percent on euro and yen to 467 percent on the peso against USD. These are spreads calculated from the "inside spread” measured as the best bid and ask price existing on the screen at a point in time. The Table 1 spreads referred to quotes from a single bank but Table 2 spreads would be 
contributed bid and ask prices from any participating bank and one would normally expect the best bid and ask prices to be contributed by different institutions at any point in time. Finally, the increase in the volatility of the average spreads are shown in the last column of Table 2. Here the numbers are most dramatic and range from a low of 158 percent for USDJPY to 5,500 percent for GBPUSD. The latter would be a fairly low volatility currency in normal times, but the pound sold off dramatically in the fall of 2008 due to the macroeconomic environment, concern over U.K. banks, and the exposure of London to the financial industry. The high volatility of the spreads reflects the thin market trading conditions. If the top of the order book has smaller than normal quantities associated with prices, then a given trade would tend to take more liquidity out of the order book than normal and the best price on that side of the market would change by a larger amount than normal so that spreads widen correspondingly by larger amounts.

Besides the risk associated with making quotes in a high-volatility environment, there was also counterparty risk to be considered. If you had exposure to an institution that went bankrupt, you were liable to lose your investment with that institution. This would apply to currency traders and the banks or prime brokers that handle their trades. If a currency trading desk had 90 day forward contracts existing with a certain bank and that bank went bankrupt, then the contracts may not be settled. Worse still, suppose a hedge fund has cash at their prime broker, and the prime broker goes bankrupt. The hedge fund may not be able to receive payment of the funds the prime broker was holding. This is exactly what happened to Lehman Brothers clients. Lehman was an important prime broker for the hedge fund industry. After the bankruptcy, the U.K. courts took over the administration of Lehman debts. Unfortunately, in the U.K. such 
proceedings are lengthy affairs and the exposed hedge funds may not receive the funds Lehman owes them for years, if at all.

One of the more interesting anecdotes associated with the Lehman bankruptcy was the story of KfW, a German state bank, who transferred EUR300 million to Lehman Brothers on Monday, September 15 related to a swap agreement, after Lehman had announced its bankruptcy. As a result, KfW lost the principal related to their transfer. ${ }^{2}$ This event only served to underscore the settlement risk that exists in the market unless trades are settled in a payment-versus-payment system like the CLS system used for settling a significant fraction of FX trades. The post-Lehman world was one where financial institutions were monitoring counterparty exposures more carefully than ever, and some institutions, considered more at risk than others, found their client base shrinking.

For the foreign exchange market, counterparty risk meant managing closely your exposures to different trading partners. It also meant finding back-up prime brokers to reduce dependence on one bank. Given liquidity and counterparty concerns, one also observed a preference for trading shorter-maturity forwards, futures, and options contracts. Rather than hold a 90 day forward contract and pay the premium for the credit and volatility risk associated with that horizon, a 30 day contract would reduce the length of the exposure and be priced at a lower risk premium. In addition, settlement risk resulted in more trades than ever being settled on the CLS system along with a significant increase in the funds, banks, and corporates seeking to join the CLS system.

\footnotetext{
2 see "KfW board members suspended over Lehman payment," guardian.co.uk, September 19, 2008 or “Deutschlands duemmste bank!” Bild.de, September 18, 2008.
} 


\subsection{The Path of Exchange Rates}

Exchange rates moved in a wide range over the 2007-2008 period. Figure 4 displays the exchange rates of the yen, euro, and British pound against the U.S. dollar. The values in Figure 4 are index values (where January 1, 2007 equals 1) of the price of one U.S. dollar in terms of each of the currencies. We see that until the first wave of the crisis in FX markets starting in August 2007, exchange rates were relatively stable. Following midAugust, the euro began to appreciate steadily against the USD. For example, in midAugust 2007 the dollar price of a euro was about 1.34. By mid-April 2008, the exchange rate was about 1.59. This was almost a 20 percent appreciation of the euro against the dollar. The euro traded within a relatively narrow range and stayed around this level until late July and then began a run of steady depreciation. By the end of October, the EURUSD exchange rate was about 1.25, a depreciation of about 22 percent. The early period was one where the U.S. subprime problems and aggressive Federal Reserve interest rate cuts were reflected in dollar weakness against the euro. The later period involved the flight-to-quality associated with the post-Lehman Brothers debacle and a strong sell-off of emerging markets, which benefited the USD.

Figure 4 illustrates that the Japanese yen was appreciating against the USD once the crisis began in August 2007. But after Bear Stearns sale and the appearance of more normal market conditions, the yen underwent a period of depreciation that ended in September 2008. In the post-Lehman world, the yen benefited from unwinding of carry trades where investors were short yen, and also from a view that the yen was a safe-haven currency. Certainly Japanese banks did not suffer from U.S. subprime exposure as did their competitors in Europe and the U.S. However, the news on the macro economy in 
Japan was progressively worse in early 2009 so that the safe-haven notion was disappearing.

Finally, the British pound had remained remarkably stable relative to USD through the early waves of the crisis. This changed in the summer of 2008 as the depth of the problems in British banks was revealed and the market began to price in the deterioration in British economic conditions resulting from the magnitude of the employment and public finance aspects of the change in financial firms in the City of London. As firms downsized and payroll was cut, tax revenues were being cut at the same time that public spending was increasing. The direct domestic impact of the decline in global financial market conditions is more important in the U.K. than anywhere else.

\subsection{The Aftermath and Predicted Implications for Liquidity}

The cost imposed by the financial crisis has resulted in a legislative and regulatory reaction to rein in risk-taking and speculative behavior. One implication has been to try and reduce compensation at banks that have accepted government assistance. In one instance, a U.K. bank paid no bonuses for 2008. The government reaction to the crisis is not surprising, but it is doubtful that those setting the rules fully understand the implications of the changes they are forcing on the financial industry.

The losses experienced by financial institutions did not come from foreign exchange trades. But the foreign exchange function is treated the same as other areas of the bank when it comes to compensation restrictions. We expect bank employees to respond in a predictable manner to a changed incentive structure. Since compensation is severely limited compared to the past, the risk/return tradeoff has changed in a manner 
that is probably consistent with public policy: less incentive to take risk results in less risk taking. For example, in the foreign exchange market, market making dealers are expected to provide liquidity to their counterparties and then manage the risk of their positions while earning a profit for their banks. Competition across banks resulted in tight spreads and a willingness to provide good two-way prices for large trade size. This willingness to bear risk on the "sell-side" was beneficial to the "buy-side" bank clients. In fact, given the large spreads reported in Tables 1 and 2 and the large volume of trading that occurred in 2008, bank profits from foreign exchange were very large. In fact, it was not uncommon to hear that a foreign exchange trader had their most profitable year ever in 2008. Yet, when bonuses were paid, they were substantially smaller than in past years. Given that they were paid much less than in the past for generating larger profits for a bank, we should expect these dealers to be less willing to warehouse the risk of carrying a currency inventory associated with their intraday trades. If they earn losses for the bank, they will be fired. If they generate large profits, they will not be paid a premium to reward successful risk taking. So conservatism results and this has adverse effects on the bank counterparties. The dealers will likely charge wider spreads and deal in smaller amounts than in the past. This will lower the risk of the bank but impose greater costs on the banks' clientele: non-bank financial institutions, corporate customers, governments, central banks, international travelers and others.

A predictable implication of the public policy response to the financial crisis is to lower liquidity and raise the risks and costs associated with non-bank currency trades. The "buy-side" faces greater costs associated with currency trading along with greater volatility of exchange rates. It should be more difficult for non-banks to transfer their 
currency risks to a bank than in the past, while the non-bank entities face greater risk in the foreign exchange market than they used to. It is not clear that there is a net gain to society from these changes.

\section{A Global Financial Stress Index}

Although our analysis has centred on the foreign exchange market, we also analysed to what extent a global measure of financial stress would have captured or confirmed these effects. Accordingly, we constructed a general financial stress index (FSI) that is similar in some respects to the index recently proposed by the International Monetary Fund (IMF) (IMF, 2008). ${ }^{3}$ One difference between the FSI we construct and the IMF version, however, is that, in operationalizing the FSI we do not use full-sample data in constructing the index (e.g. by fitting generalised autoregressive conditional heteroskedasticity, GARCH, models using the full-sample data or subtracting off fullsample means). In other essential respects, however, our FSI is similar to the IMF version and we examine the same group of seventeen developed countries as in the IMF study, namely: Australia, Austria, Belgium, Canada, Denmark, Finland, France, Germany, Italy, Japan, Netherlands, Norway, Spain, Sweden, Switzerland, the UK and the USA. In contrast to the IMF analysis, however, we built a 'global' FSI based on an average of the individual FSI for each of these seventeen countries.

The FSI is a composite variable built using market-based indicators in order to capture four essential characteristics of a financial crisis: large shifts in asset prices, an abrupt increase in risk and uncertainty, abrupt shifts in liquidity and a measurable decline in banking system health indicators.

\footnotetext{
${ }^{3}$ See also Illing and Liu (2006).
} 
In the banking sector, three indicators were used:

i) The beta of banking sector stocks, constructed as the twelve-month rolling covariance of the year-over-year percent change of a country's banking sector equity index and its overall stock market index, divided by the rolling twelvemonth variance of the year-over-year percent change of the overall stock market index.

ii) The spread between interbank rates and the yield on Treasury Bills, i.e. the socalled TED spread that we discussed above: three-month LIBOR or commercial paper rate minus the government short-term rate.

iii) The slope of the yield curve, or inverted term spread: the government shortterm Treasury Bill yield minus the government long-term bond yield.

In the securities market, a further three indicators were used:

i) Corporate bond spreads: the corporate bond yield minus the long-term government bond yield.

ii) Stock market returns: the monthly percentage change in the country equity market index.

iii) Time-varying stock return volatility. This was calculated as the square root of an exponential moving average of squared deviations from an exponential moving average of national equity market returns. An exponential moving average with a 36-month half-life was used in both cases.

Finally, in the foreign exchange market: 
i) For each country a time-varying measure of real exchange volatility was similarly calculated - i.e. the square root of an exponential moving average of squared deviations from an exponential moving average of monthly percentage real effective exchange rate changes. An exponential moving average with a 36-month half-life was used in both cases.

All components of the FSI are in monthly frequency and each component is scaled to be equal to 100 at the beginning of the sample. A national FSI index is constructed for each country by taking an equally weighted average of the various components. Then, a global FSI index is constructed by taking an equally weighted average of the seventeen national FSI indices. The calculated global FSI series runs from December 1983 until October 2008.

In order to ascertain whether an extreme value of the FSI has been breached, we scored the FSI by subtracting off a time-varying mean (calculated using an exponential moving average with a 36-month half-life) and dividing through by a time-varying standard deviation (calculated taking the square root of an exponential moving average, with a 36-month half-life, of the squared deviations from the time-varying mean). The resulting scored FSI gives a measure of the how many standard deviations the FSI is away from its time-varying mean.

As can be seen from Figure 5, the global FSI crosses the threshold of one standard deviation above the mean for most of the major crises of the past twenty years or so, 
including the 1987 stock market crash, the Nikkei/junk bond collapse of the late 1980s, the 1990 Scandinavian banking crisis and the 1998 Russian default/LTCM crisis. The 1992 ERM crisis is less evident at the global level.

Most interestingly, however, the global FSI shows a very marked effect during the current crisis. Mirroring the carry unwind in August 2007 that we documented above, there is a brief lull in the FSI as it drops below one standard deviation from its mean before leaping up again in November 2007 to nearly 1.5 standard deviations from the mean,. The global FSI then breaches the two-standard deviation threshold in January 2008 and again in March 2008 (coinciding with the near collapse of Bear Stearns). With the single exception of a brief lull in May 2008, when the global FSI falls to about 0.7 standard deviations above the mean, it then remains more than one standard deviation above the mean for the rest of the sample, spiking up in October to more than four standard deviations from the mean following the Lehman Brothers debacle in September.

It is tempting to infer from this analysis that an active currency manager could have significantly defended their portfolio by taking risk off (or perhaps even going short carry) in August 2007, especially as the carry unwind documented in Figure 1 is confirmed as a crisis point by the movements in the global FSI in the same month. We carried out a first exploration of this idea by estimating a Probit model of significant drawdowns from the carry trade investment as a function of the global FSI, where a "significant drawdown" is defined as greater than a one standard deviation negative return. Table 3 presents the estimation results. Clearly, the probability of a major drawdown from a carry trade investment is increasing in the FSI. Table 3 yields evidence 
of statistical significance of the effect of the FSI on the carry trade. ${ }^{4}$ What about economic significance?

To examine the economic significance of the FSI effects on carry trade returns, we simulate the returns an investor would earn from investing in the Deutsche Bank Carry Return Index. Suppose the investor just invests in the index in an unconditional sense, without regard to market conditions. We will call this the "Unconditional Return." Alternatively, the investor can invest in the index in "normal" periods and close out the position in stressful periods, where stress is measured by the global FSI. Specifically, when the FSI exceeds a value of 1, the carry trade exposure is shut off; otherwise, the investment is held. Figure 6 illustrates the cumulative returns to such strategies. The cumulative unconditional return is $-1 \%$ while the conditional return is $+38 \%$ over the period studied.

Our carry-trade horse race clearly indicates a superior performance of conditioning the carry trade investment on the FSI. In more familiar investment metrics, over the entire 2000-2008 period studied, the unconditional strategy yielded an information ratio (IR, measuring return per unit of risk) equal to -0.03 while the conditional return yields an IR of 0.69. Over the more recent 2005-2008 period, the unconditional IR is -0.66 while the conditional IR is 0.31 . In this regard, we see that the FSI as a risk indicator has potential value to FX investments.

Caveats regarding this analysis are as follows:

1) These results ignore transaction costs. This is important as when the FSI signals significant stress, market conditions are such that we should observe widespread carry

\footnotetext{
${ }^{4}$ A consideration of factors that might control carry trade losses is receiving increased attention in the literature lately. Some examples are Brunnermeier, Nagel, and Pedersen (2008); Jurek (2007); and Clarida, Davis, and Pedersen (2009).
} 
trade unwinding. So an investor will face large one-sided market conditions that will lead to a much greater than normal cost of trading. Tables 1 and 2 provided indicative information on how much bid-ask spreads widened in the post-Lehman Brothers period. This is also indicative of what one might expect during a period of major carry unwind. Furthermore, investors seeking to sell out of their carry positions will face very thin offers on the other side of their trade. For instance, to close out the carry trade strategy of short yen (JPY), long New Zealand dollar (NZD) would involve buying JPY and selling NZD. But if there is great interest to do the same trade across the market, there will be very little flow interested in selling JPY and buying NZD, so market makers will price trades accordingly so that the price of exiting the carry trade will be much higher than in normal times.

2) These results assume the carry trade exposure is eliminated in the same month that the FSI signals stress. There may be a lag between recognition of the market stress and exiting the position. If the carry trade exposure is eliminated in the month following the FSI signal of stress, the IR falls from 0.69 to 0.42 over the entire 2000-2008 sample period and from 0.66 to 0.00 over the recent 2005-2008 period. If the investor cannot recognize the shift to the stressful state in real time, it may be too late in many cases to reduce carry trade exposure.

\section{Conclusions}

The financial crisis of 2007-? has had major implications for the foreign exchange market. In the earlier part of this paper, we reviewed events and implications for exchange rates, volatility, returns to currency investing, and transaction costs. This "blow-by-blow" 
narrative is intended to be a resource for researchers seeking a comprehensive review of the "what, why and when" of the crisis in the foreign exchange market.

The crisis began in August 2007, when subprime-related turmoil in other asset classes finally spilled over into the currency market. This initial phase of the crisis was manifested in a major carry trade sell-off. Then in November 2007, credit restrictions were associated with a major deleveraging in financial markets and many investment funds were forced to liquidate positions. The next major wave of the crisis arrived in March 2008 with the near-failure of Bear Stearns. The treatment of Bear Stearns as "too big to fail” and the orderly takeover by JP Morgan Chase appeared to calm the market so that some semblance of normality returned to financial markets. The peak of the crisis (at least, so far) was the September 2008 failure of Lehman Brothers. By any metric, the crisis in the wake of the Lehman Brothers bankruptcy was unlike anything that had preceded this period: volatility reached unseen levels, liquidity disappeared as counterparty risk reached unprecedented levels so that the cost of trading currencies skyrocketed and it became very difficult to trade any substantial size.

In the later part of the paper, we developed a financial stress index (FSI) that is an operationalized, global version of the FSI suggested by the IMF, and we then used the global FSI to illustrate the dramatic nature of the current crisis compared to earlier crises. We also examined how the global FSI might have been used to condition the exposure to the carry trade (long high interest rate currencies, short low interest rate currencies) and we showed that such an index has potential value in protecting a portfolio against loss during period of stress, although this result is subject to the important caveats of controlling for transaction costs and timely recognition of the change in regime. 


\section{References}

Brunnermeir , M., Nagel, S., Pedersen, L., 2008. Carry trades and currency crashes. NBER Macroeconomics Annual, 2008.

Cai, J., Cheung, Y, Lee, R., Melvin, M., 2001. Once in a generation yen volatility in 1998: fundamentals, intervention, and order flow. Journal of International Money \& Finance 20, 327-347.

Clarida, R., Davis, J., Pedersen, N., 2009. Currency carry trade regimes: beyond the Fama regression. Working Paper.

Illing, M., Liu, Y., 2006. Measuring financial stress in a developed country: an application to Canada. Journal of Financial Stability 2, 243-265.

International Monetary Fund, 2008. Financial stress and economic downturns. World Economic Report: Chapter 4, 129-158.

Jurek, J., 2007. Crash-neutral currency carry trades. Princeton, Bendheim Center for Finance, Working Paper. 
Table 1: FX Bid-Ask Spreads for \$50million: Comparing Normal to Post-Lehman Period

Values are for risk-transfer trades in the range of \$50-100 million, where a counterparty requests a two-way price from a market-maker in a bilateral transaction. These should be considered representative of the periods under consideration. Larger trades would generally have wider spreads. Values are in "pips," for instance if the spread on EURUSD is 1, then the spread would be something like 1.3530-1.3531. Both spot and 3-month forward swap spreads are given.

\begin{tabular}{|c|c|c|c|c|}
\hline & \multicolumn{2}{|c|}{ Pre-Crisis 2007 Period } & \multicolumn{2}{|c|}{ Post-Lehman Crisis Period } \\
\hline & spot & 3-mo swap & spot & 3-mo swap \\
\hline EURUSD & 1 & 0.2 & 5 & 10 \\
\hline GBPUSD & 3 & 0.3 & 12 & 12 \\
\hline USDJPY & 3 & 0.2 & 12 & 10 \\
\hline USDCHF & 4 & 0.4 & 16 & 15 \\
\hline AUDUSD & 4 & 0.4 & 20 & 20 \\
\hline USDCAD & 4 & 0.3 & 20 & 30 \\
\hline NZDUSD & 8 & 0.5 & 40 & 10 \\
\hline
\end{tabular}


Table 2

The Increase in FX Transactions and Spreads on Electronic Crossing Networks: Pre-crisis to Post-crisis

The table shows the percentage change from the Sept-Oct 2007 period to the Sept-Oct 2008 period in a) the number of transactions in each currency pair, b) the average bid-offer spread, and c) the volatility of the spread as collected from the EBS and Reuters electronic brokerage systems. Source: RBS.

\begin{tabular}{|l|l|l|l|}
\hline & $\%$ increase in total transactions & $\begin{array}{l}\% \text { increase in avg bid-offer } \\
\text { spread }\end{array}$ & $\begin{array}{l}\text { \% increase in volatility of avg } \\
\text { bid-offer spread }\end{array}$ \\
\hline EURUSD & $92 \%$ & $60 \%$ & $336 \%$ \\
\hline USDJPY & $58 \%$ & $60 \%$ & $158 \%$ \\
\hline GBPUSD & $28 \%$ & $293 \%$ & $5500 \%$ \\
\hline AUDUSD & $81 \%$ & $127 \%$ & $1212 \%$ \\
\hline USDMXN & $36 \%$ & $467 \%$ & $715 \%$ \\
\hline USDZAR & $75 \%$ & $135 \%$ & $412 \%$ \\
\hline
\end{tabular}


Table 3

Carry Trade Investment Drawdowns and the Financial Stress Index

The table reports results of a Probit regression estimation of periods of significant negative returns to an investment in the Deutsche Bank Carry Index as a function of the Financial Stress Index (FSI). A significant drawdown is defined as a greater than 1 standard deviation (0.0247) negative return in a month. The results suggest statistically significant effects of greater financial stress in the market increasing the probability of a significant drawdown.

Dependent Variable: NEGRET

Method: ML - Binary Probit (Quadratic hill climbing)

Sample: 2000M01 2008M10

Included observations: 106

Convergence achieved after 5 iterations

Covariance matrix computed using second derivatives

\begin{tabular}{lrlrr}
\hline \hline & Coefficient & Std. Error & Z-Statistic & Prob. \\
\hline \hline \multicolumn{1}{c}{ constant } & -1.436662 & 0.196568 & -7.308709 & 0.0000 \\
\multicolumn{1}{c}{ FSI } & 0.446948 & 0.143449 & 3.115719 & 0.0018 \\
\hline \hline McFadden R & & & \\
S.D. of dep. variable & 0.142782 & Mean of dependent variable & 0.113208 \\
Akaike info criterion & 0.318352 & S.E. of regression & 0.290921 \\
Schwarz criterion & 0.643222 & Sum of squared residuals & 8.802070 \\
Hannan-Quinn criterion & 0.693476 & Log likelihood & -32.09079 \\
LR statistic & 0.663591 & Restricted log likelihood & -37.43595 \\
Prob(LR statistic) & 10.69033 & Average log likelihood & -0.302743 \\
\hline \hline Obs. with NEGRET=0 & 0.001077 & & 106 \\
Obs with NEGRET=1 & 94 & Total obs. & \\
\hline
\end{tabular}


Figure 1: Deutsche Bank Carry index

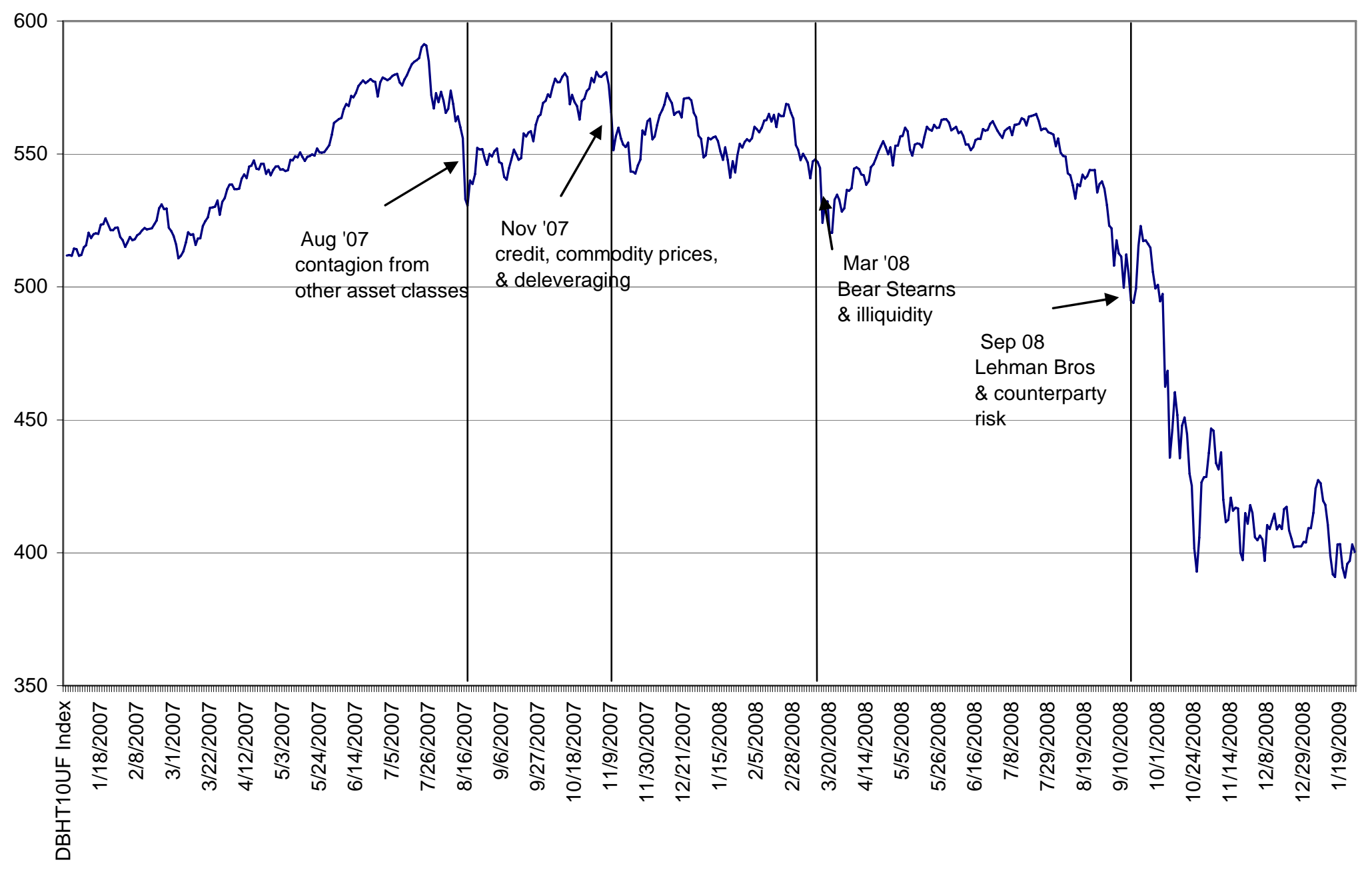


Figure 2: AUDJPY 1mo Implied Volatility

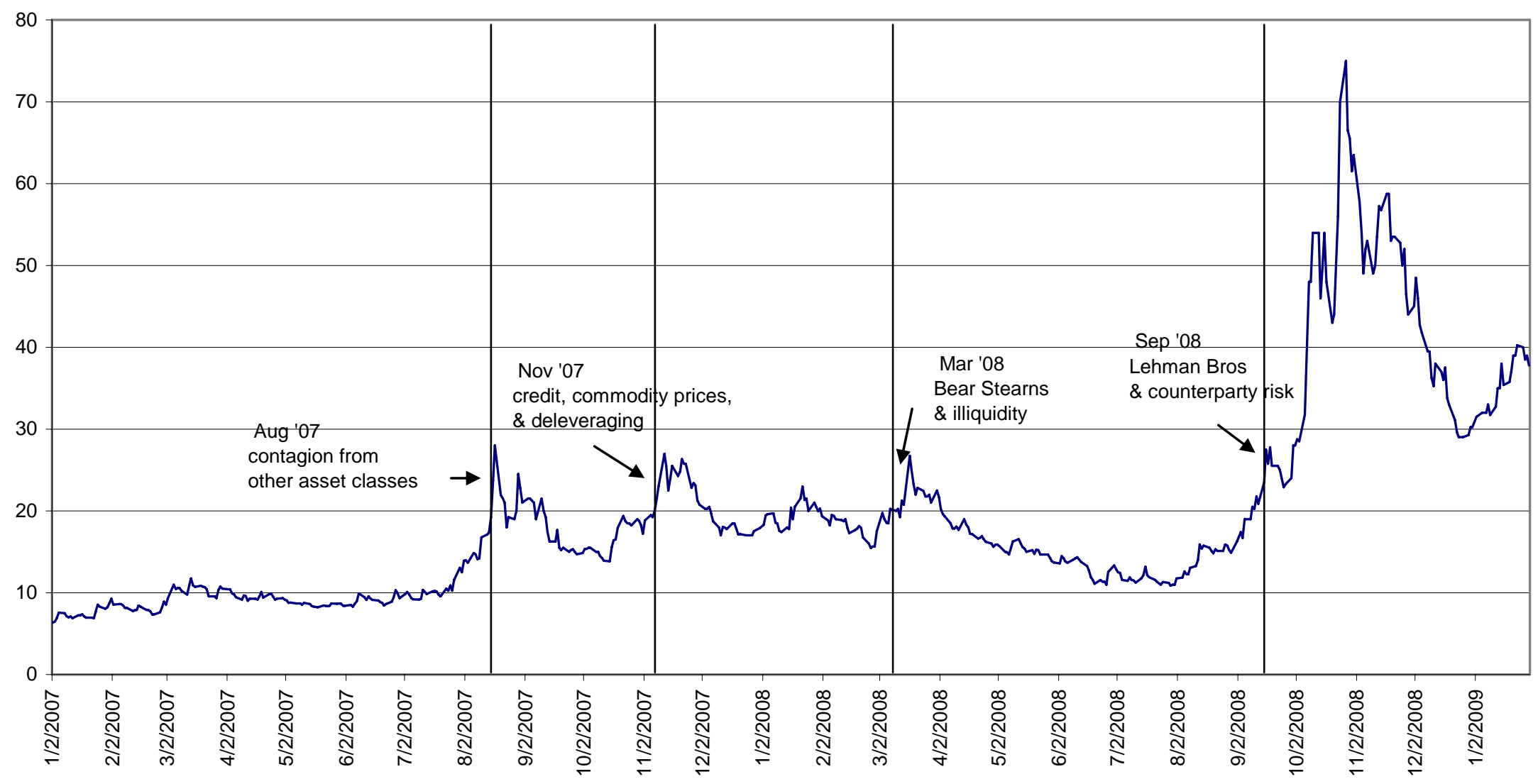


Figure 3: TED Spread

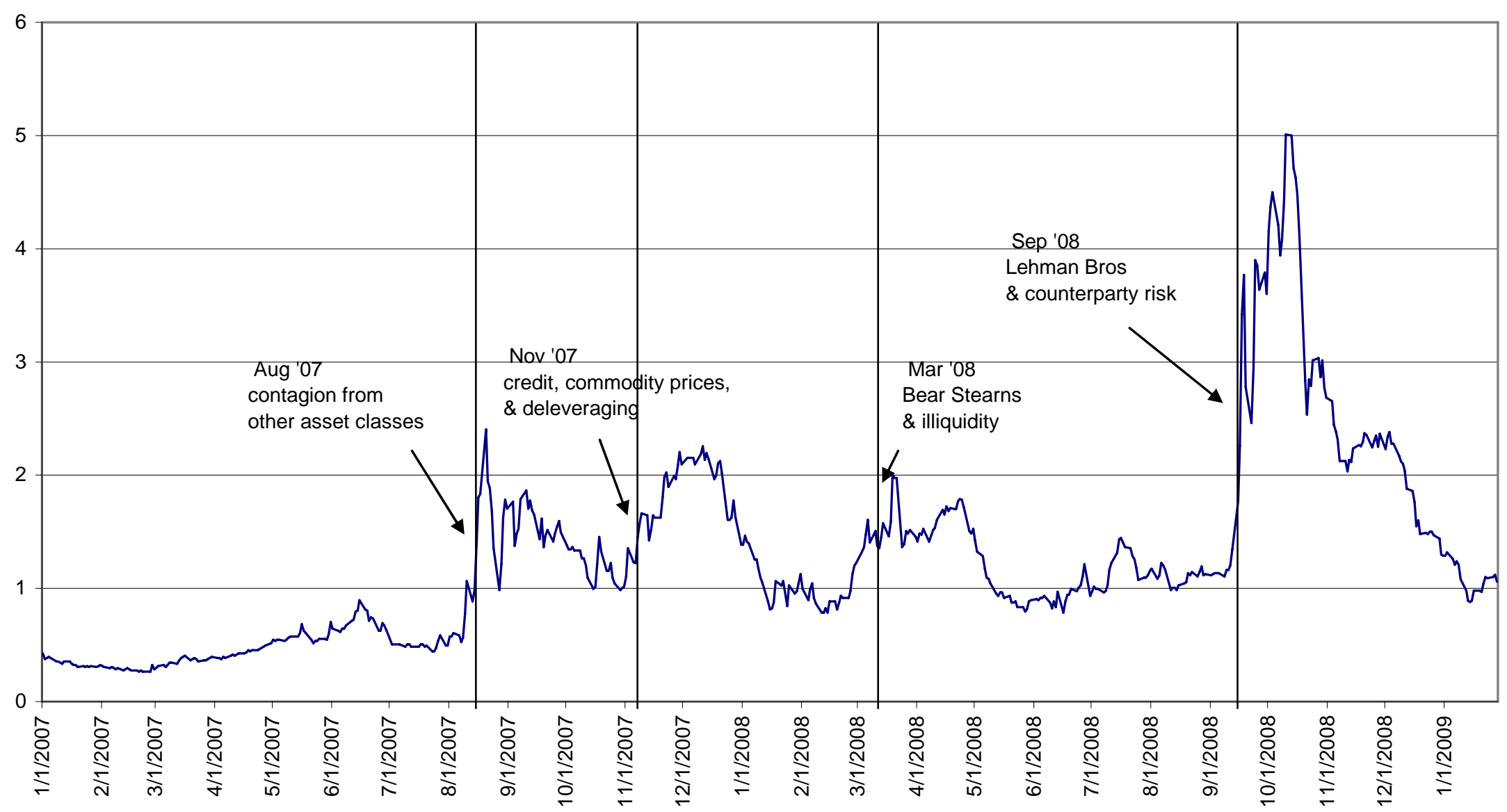


Figure 4: Major Currency Exchange Rates

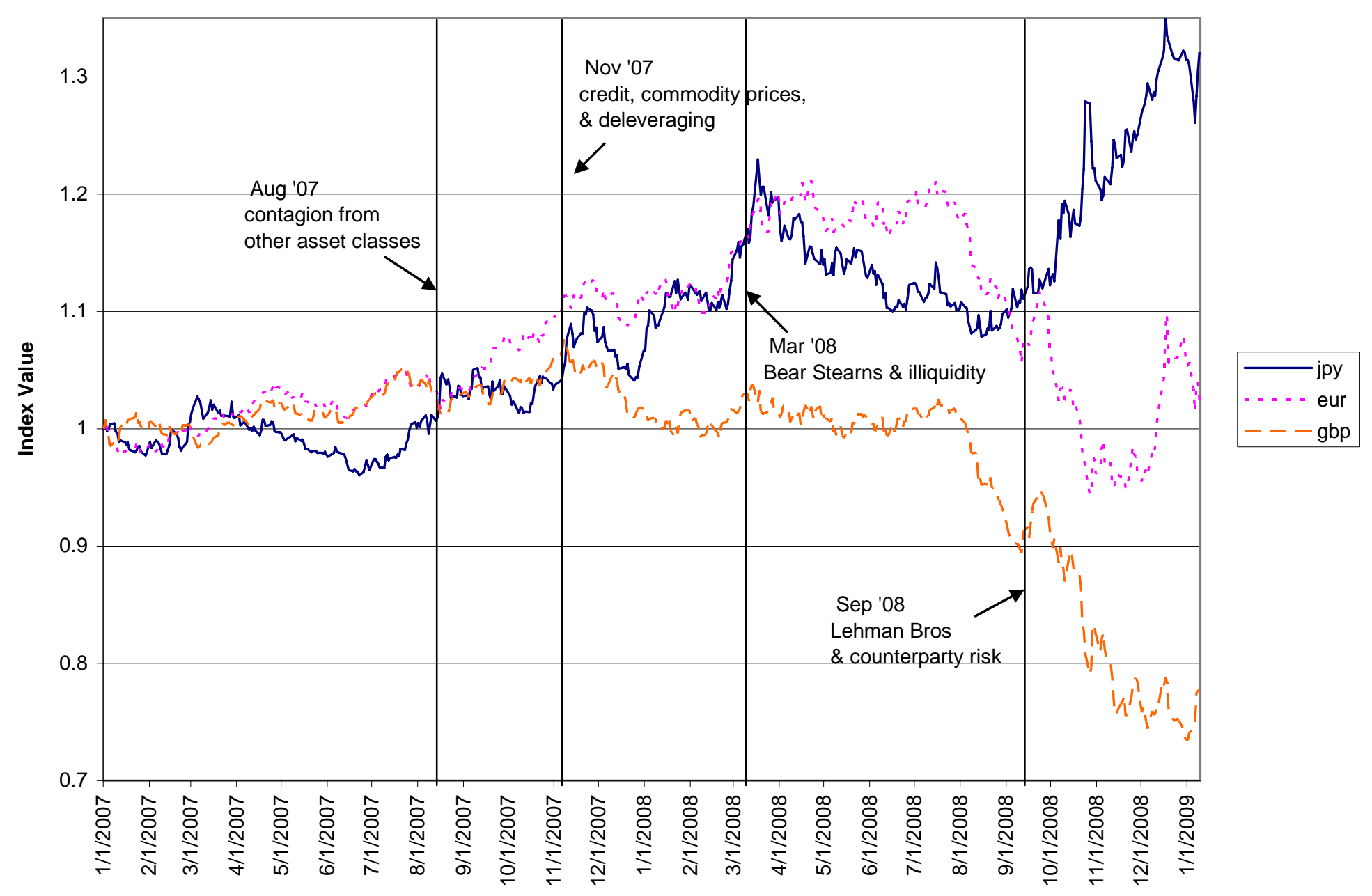


Figure 5: Scored Global Financial Stress Index

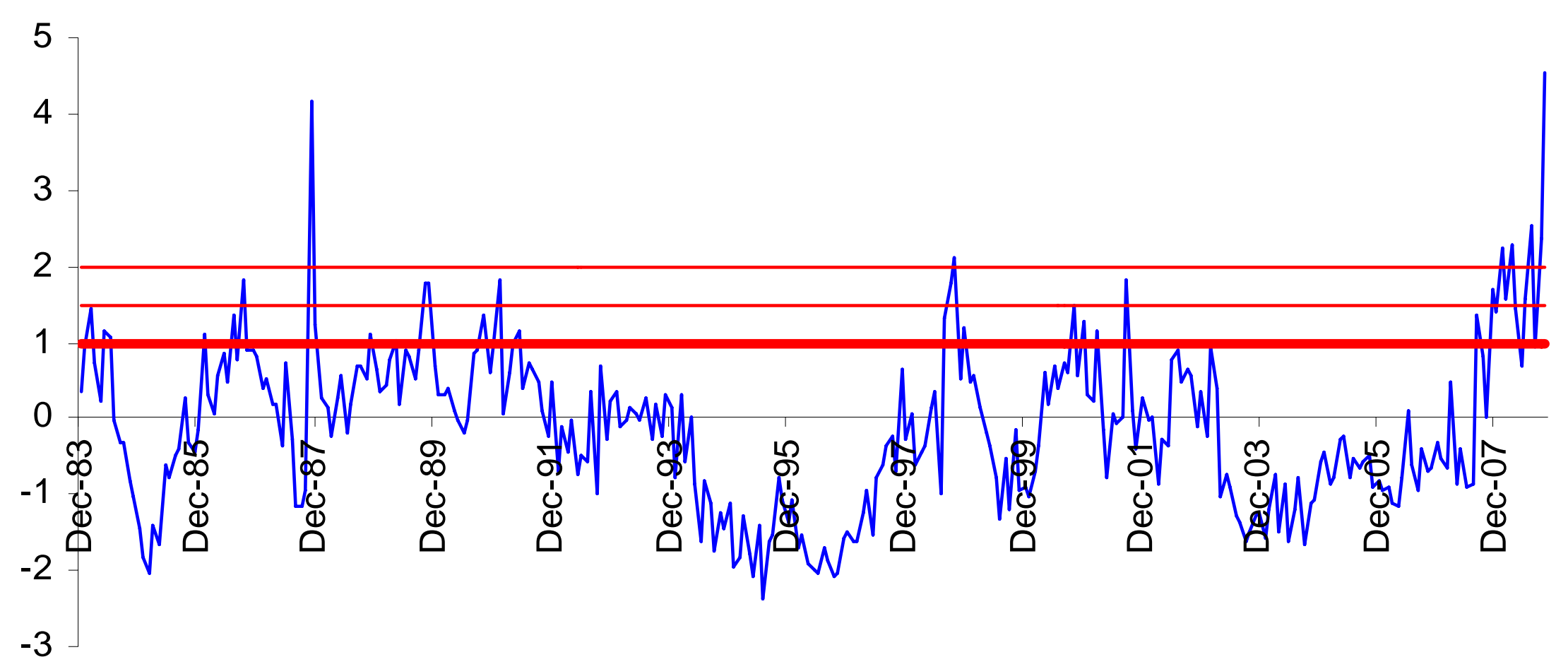




\section{Figure 6: The Returns to the Carry Trade}

The graph illustrates the cumulative returns to an investment in the Deutsche Bank Carry Index. In the unconditional case, the investor simply maintains the investment regardless of market conditions. In the conditioned case, the investment is shut off when the Global FSI index of financial market risk signals a particularly stressful period.

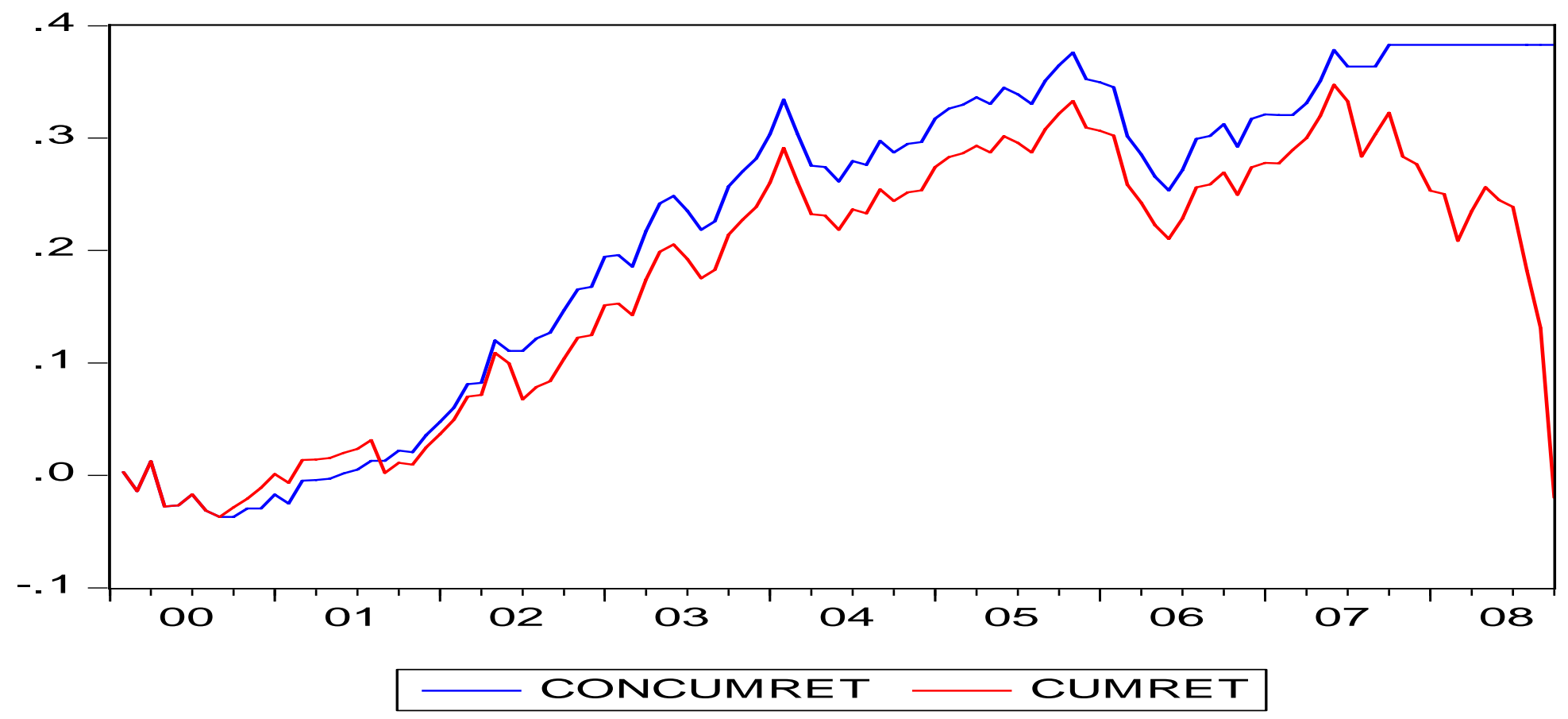




\section{CESifo Working Paper Series}

for full list see www.cesifo-group.org/wp

(address: Poschingerstr. 5, 81679 Munich, Germany, office@cesifo.de)

2645 Dominique Demougin, Oliver Fabel and Christian Thomann, Implicit vs. Explicit Incentives: Theory and a Case Study, May 2009

2646 Francesco C. Billari and Vincenzo Galasso, What Explains Fertility? Evidence from Italian Pension Reforms, May 2009

2647 Kjell Arne Brekke, Karen Evelyn Hauge, Jo Thori Lind and Karine Nyborg, Playing with the Good Guys - A Public Good Game with Endogenous Group Formation, May 2009

2648 Guglielmo Maria Caporale and Luis A. Gil-Alana, Multi-Factor Gegenbauer Processes and European Inflation Rates, May 2009

2649 Henning Bohn, A Static Model for Voting on Social Security, May 2009

2650 Markus Haavio and Kaisa Kotakorpi, The Political Economy of Sin Taxes, May 2009

2651 Augusto de la Torre, María Soledad Martínez Pería and Sergio L. Schmukler, Drivers and Obstacles to Banking SMEs: The Role of Competition and the Institutional Framework, May 2009

2652 Tobias Lindhe and Jan Södersten, Dividend Taxation, Share Repurchases and the Equity Trap, May 2009

2653 Assaf Razin and Edith Sand, Migration-Regime Liberalization and Social Security: Political-Economy Effect, May 2009

2654 Yin-Wong Cheung and Hiro Ito, A Cross-Country Empirical Analysis of International Reserves, May 2009

2655 Bart Cockx and Bruno Van der Linden, Flexicurity in Belgium. A Proposal Based on Economic Principles, May 2009

2656 Michael Melvin, Lukas Menkhoff and Maik Schmeling, Exchange Rate Management in Emerging Markets: Intervention via an Electronic Limit Order Book, May 2009

2657 Susanne Neckermann, Reto Cueni and Bruno S. Frey, What is an Award Worth? An Econometric Assessment of the Impact of Awards on Employee Performance, May 2009

2658 Steven Brakman, Harry Garretsen and Charles van Marrewijk, Economic Geography within and between European Nations: The Role of Market Potential and Density across Space and Time, May 2009 
2659 Giovanni Facchini and Cecilia Testa, Reforming Legislatures: Is one House better than two?, May 2009

2660 Carsten Kowalczyk and Raymond Riezman, Trade Agreements, May 2009

2661 Oliver Falck, Stephan Heblich and Elke Luedemann, Identity and Entrepreneurship, May 2009

2662 Christian Lessmann and Gunther Markwardt, One Size Fits All? Decentralization, Corruption, and the Monitoring of Bureaucrats, May 2009

2663 Felix Bierbrauer, On the Legitimacy of Coercion for the Financing of Public Goods, May 2009

2664 Alessandro Cigno, Agency in Family Policy: A Survey, May 2009

2665 Claudia M. Buch and Christian Pierdzioch, Low Skill but High Volatility?, May 2009

2666 Hendrik Jürges, Kerstin Schneider, Martin Senkbeil and Claus H. Carstensen, Assessment Drives Learning: The Effect of Central Exit Exams on Curricular Knowledge and Mathematical Literacy, June 2009

2667 Eric A. Hanushek and Ludger Woessmann, Schooling, Cognitive Skills, and the Latin American Growth Puzzle, June 2009

2668 Ourania Karakosta, Christos Kotsogiannis and Miguel-Angel Lopez-Garcia, Does Indirect Tax Harmonization Deliver Pareto Improvements in the Presence of Global Public Goods?, June 2009

2669 Aleksandra Riedl and Silvia Rocha-Akis, Testing the Tax Competition Theory: How Elastic are National Tax Bases in OECD Countries?, June 2009

2670 Dominique Demougin and Carsten Helm, Incentive Contracts and Efficient Unemployment Benefits, June 2009

2671 Guglielmo Maria Caporale and Luis A. Gil-Alana, Long Memory in US Real Output per Capita, June 2009

2672 Jim Malley and Ulrich Woitek, Productivity Shocks and Aggregate Cycles in an Estimated Endogenous Growth Model, June 2009

2673 Vivek Ghosal, Business Strategy and Firm Reorganization under Changing Market Conditions, June 2009

2674 Francesco Menoncin and Paolo M. Panteghini, Retrospective Capital Gains Taxation in the Real World, June 2009

2675 Thomas Hemmelgarn and Gaëtan Nicodème, Tax Co-ordination in Europe: Assessing the First Years of the EU-Savings Taxation Directive, June 2009 
2676 Oliver Himmler, The Effects of School Competition on Academic Achievement and Grading Standards, June 2009

2677 Rolf Golombek and Michael Hoel, International Cooperation on Climate-Friendly Technologies, June 2009

2678 Martin Cave and Matthew Corkery, Regulation and Barriers to Trade in Telecommunications Services in the European Union, June 2009

2679 Costas Arkolakis, A Unified Theory of Firm Selection and Growth, June 2009

2680 Michelle R. Garfinkel, Stergios Skaperdas and Constantinos Syropoulos, International Trade and Transnational Insecurity: How Comparative Advantage and Power are Jointly Determined, June 2009

2681 Marcelo Resende, Capital Structure and Regulation in U.S. Local Telephony: An Exploratory Econometric Study; June 2009

2682 Marc Gronwald and Janina Ketterer, Evaluating Emission Trading as a Policy Tool Evidence from Conditional Jump Models, June 2009

2683 Stephan O. Hornig, Horst Rottmann and Rüdiger Wapler, Information Asymmetry, Education Signals and the Case of Ethnic and Native Germans, June 2009

2684 Benoit Dostie and Rajshri Jayaraman, The Effect of Adversity on Process Innovations and Managerial Incentives, June 2009

2685 Peter Egger, Christian Keuschnigg and Hannes Winner, Incorporation and Taxation: Theory and Firm-level Evidence, June 2009

2686 Chrysovalantou Milliou and Emmanuel Petrakis, Timing of Technology Adoption and Product Market Competition, June 2009

2687 Hans Degryse, Frank de Jong and Jérémie Lefebvre, An Empirical Analysis of Legal Insider Trading in the Netherlands, June 2009

2688 Subhasish M. Chowdhury, Dan Kovenock and Roman M. Sheremeta, An Experimental Investigation of Colonel Blotto Games, June 2009

2689 Alexander Chudik, M. Hashem Pesaran and Elisa Tosetti, Weak and Strong Cross Section Dependence and Estimation of Large Panels, June 2009

2690 Mohamed El Hedi Arouri and Christophe Rault, On the Influence of Oil Prices on Stock Markets: Evidence from Panel Analysis in GCC Countries, June 2009

2691 Lars P. Feld and Christoph A. Schaltegger, Political Stability and Fiscal Policy - Time Series Evidence for the Swiss Federal Level since 1849, June 2009

2692 Michael Funke and Marc Gronwald, A Convex Hull Approach to Counterfactual Analysis of Trade Openness and Growth, June 2009 
2693 Patricia Funk and Christina Gathmann, Does Direct Democracy Reduce the Size of Government? New Evidence from Historical Data, 1890-2000, June 2009

2694 Kirsten Wandschneider and Nikolaus Wolf, Shooting on a Moving Target: Explaining European Bank Rates during the Interwar Period, June 2009

2695 J. Atsu Amegashie, Third-Party Intervention in Conflicts and the Indirect Samaritan's Dilemma, June 2009

2696 Enrico Spolaore and Romain Wacziarg, War and Relatedness, June 2009

2697 Steven Brakman, Charles van Marrewijk and Arjen van Witteloostuijn, Market Liberalization in the European Natural Gas Market - the Importance of Capacity Constraints and Efficiency Differences, July 2009

2698 Huifang Tian, John Whalley and Yuezhou Cai, Trade Sanctions, Financial Transfers and BRIC's Participation in Global Climate Change Negotiations, July 2009

2699 Axel Dreher and Justina A. V. Fischer, Government Decentralization as a Disincentive for Transnational Terror? An Empirical Analysis, July 2009

2700 Balázs Égert, Tomasz Koźluk and Douglas Sutherland, Infrastructure and Growth: Empirical Evidence, July 2009

2701 Felix Bierbrauer, Optimal Income Taxation and Public Goods Provision in a Large Economy with Aggregate Uncertainty, July 2009

2702 Marc Gronwald, Investigating the U.S. Oil-Macroeconomy Nexus using Rolling Impulse Responses, July 2009

2703 Ali Bayar and Bram Smeets, Government Deficits in the European Union: An Analysis of Entry and Exit Dynamics, July 2009

2704 Stergios Skaperdas, The Costs of Organized Violence: A Review of the Evidence, July 2009

2705 António Afonso and Christophe Rault, Spend-and-tax: A Panel Data Investigation for the EU, July 2009

2706 Bruno S. Frey, Punishment - and beyond, July 2009

2707 Michael Melvin and Mark P. Taylor, The Crisis in the Foreign Exchange Market, July 2009 